\title{
Influence of groundwater quality indicators on nitrate concentrations in the Zagreb aquifer system
}

\author{
Zoran Kovač, Zoran Nakić and Krešimir Pavlić \\ University of Zagreb, Faculty of Mining, Geology and Petroleum Engineering, Pierottijeva 6, 10000 Zagreb, Croatia; (zoran.kovac@rgn.hr)
}

doi: $10.4154 / g c .2017 .08$

Article history:

Manuscript received January 31, 2017

Revised manuscript accepted April 24, 2017 Available online June 28, 2017
Keywords: nitrates, groundwater quality indicators, Zagreb aquifer system, multivariate statistical analysis

\begin{abstract}
Nitrates represent one of the main groups of contaminants in the Zagreb aquifer system. Some natural groundwater quality indicators can have a significant influence on their stability and mobility in the saturated zone. Correlation and multivariate statistical analyses were used to test the correlation of average values of $\mathrm{NO}_{3}{ }^{-}$with $\mathrm{O}_{2}, \mathrm{ORP}, \mathrm{pH}, \mathrm{EC}$ and temperature of groundwater, and to allocate observation wells that belong to the same clusters. ORP values didn't relate to any observed variables, which is probably due to their variability which suggests changes in the oxidation-reduction conditions in the aquifer system. Principal component analysis was used for the determination of variables that are related to the nitrate concentrations and which were then used in cluster analysis. Other variables were excluded from cluster analysis. Three methods were used to perform cluster analysis, where the results calculated with Ward's method were chosen as the most appropriate. In the end, two clusters were identified, one with smaller, and one with higher $\mathrm{NO}_{3}^{-}, \mathrm{O}_{2}$ and $\mathrm{EC}$ values. Observation wells from cluster 1 are generally located near the Sava River and have similar nitrate concentrations. Lack of other nitrogen species and moderately aerobic conditions suggest very fast nitrification in the shallow Holocene aquifer.
\end{abstract}

\section{INTRODUCTION}

Nitrates represent one of the most frequent groundwater contaminants in the world (PEÑA-HARO et al., 2009) and in Croatia (LARVA et al., 2010; NAKIĆ et al., 2013). Due to their inability to bond in soil by adsorption, they are subject to leaching and infiltration into deeper soil layers and groundwater (CHOWDARY et al., 2005; MKANDAWIRE, 2008). When they reach groundwater, they mostly depend on transport and geochemical processes in saturated media. Many studies have shown strong relationships between agricultural activity and nitrate concentrations in groundwater (ALMASRI, 2007; PEÑA-HARO et al., 2009; LI et al., 2010; HOSONO et al., 2013). Also, nitrate concentrations can be a consequence of the simultaneous influence of other anthropogenic sources, e.g. septic tanks, sewage and landfills. Despite this, there are also different natural factors that have both an influence on their stability and their mobility through the unsaturated and saturated zones. Nitrate concentrations can depend on the depth to aquifer, recharge, aquifer media, soil media, topography, impact of vadose zone media, hydraulic conductivity, surface leaching and aquifer type (ALLER et al., 1987; LAKE et al., 2003). Nitrate leaching from the unsaturated zone is a consequence of complex interactions between many factors, e.g. soil characteristics, nitrogen dynamics, depth to water table, land use practice, on-ground nitrogen loading and recharge (ALMASRI, 2003; 2007). DIMKIĆ et al. (2008) stated that nitrate concentrations can be predominantly found in aerobic media, where they have high mobility. Other nitrogen species, like nitrite and ammonium ions, are generally stable in predominantly anaerobic media. There are different indicators of aerobic and anaerobic conditions, but concentrations of dissolved oxygen $\left(\mathrm{O}_{2}\right)$ and the oxidation-reduction potential (ORP) represent the most important ones. Concentrations of dissolved oxygen between 1 and $2 \mathrm{mg} / \mathrm{l}$, and ORP values between 150 to $200 \mathrm{mV}$, represent the approximate threshold values for defining the boundary between aerobic and anaerobic conditions. KOVAČ et al. (2016) showed that there is a statistically significant positive correlation between nitrate and dissolved oxygen concentrations in the Zagreb aquifer. Correlation and multivariate statistical analyses are very often used in geochemical research and the identification of potential nitrate contaminant sources (VIDAL et al., 2000; JEONG, 2001; MORATALLA et al., 2009). Even though nitrates are defined as one of the main group of contaminants in the study area (NAKIĆ et al., 2013), and are generally the consequence of anthropogenic influence, the main objective of this work was to define and quantify the correlation of five natural indicators, i.e. $\mathrm{O}_{2}, \mathrm{ORP}, \mathrm{pH}$, electrical conductivity (EC) and temperature of groundwater, on nitrate $\left(\mathrm{NO}_{3}{ }^{-}\right)$concentrations in the Zagreb aquifer system. For this purpose, correlation and multivariate statistical analyses (principal component and cluster analysis) were used. Principal component analysis (PCA) was used for the reduction of variables that were then used in cluster analysis with the purpose of identifying groups of observation wells with similar characteristics.

\section{RESEARCH AREA}

The Zagreb aquifer system is located in the NW part of the Republic of Croatia (Fig. 1) and it represents the only source of potable water for the inhabitants of the City of Zagreb and Zagreb County. The Zagreb aquifer system is designated as a part of country's strategic water reserves. It is located between Medvednica Mountain in the north and the Vukomeričke Gorice hills in the south and it covers an area of approximately $350 \mathrm{~km}^{2}$. The wider region is characterized by great variability in lithology, land use, pedological features and the hydraulic properties of the aquifers.

The Zagreb aquifer system is composed of sediments of Quaternary age, deposited during the Middle and Upper Pleistocene and Holocene. Pleistocene deposits are represented by lacustrine-marshy deposits, while Holocene ones are alluvial de- 


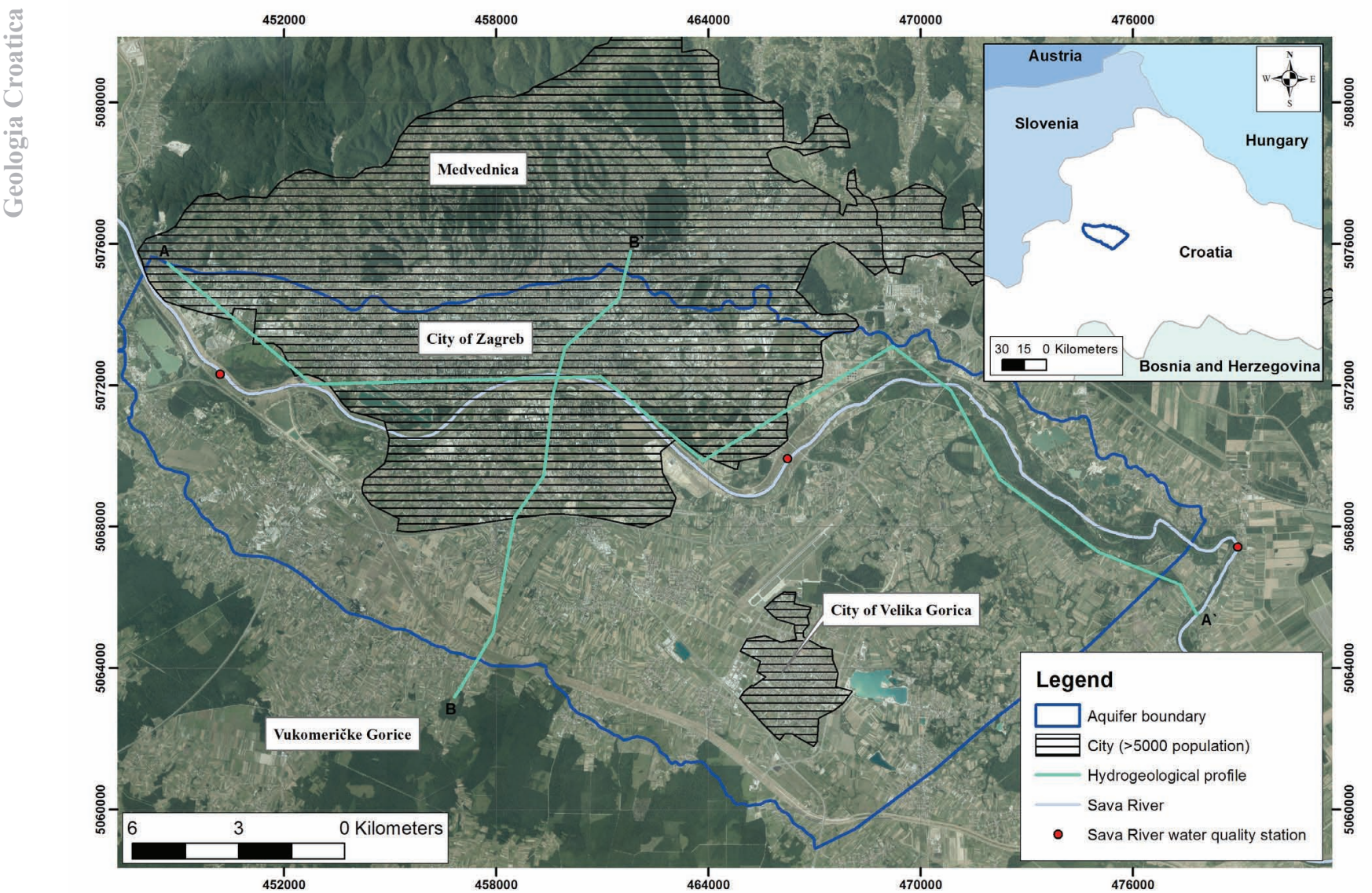

Figure 1. Research area.

posits. Microfaunal and microfloral analysis were used for the definition of the main stratigraphic units (SOKAČ, 1978; HERNITZ et al., 1981). Changes in the sedimentary environment and petrographical origin of the clasts in gravels and sands was used for the determination of the boundary between Pleistocene and Holocene deposits. In the beginning of the Holocene, the Sava River started to flow and transport material from the Alps which was mainly carbonate, in contrast to the Pleistocene deposits, which were generally siliciclastic (VELIĆ \& SAFTIĆ, 1991). Overall, Lower Pleistocene deposits are mostly composed of clayey silts and silty clays with sporadic interbeds and lenses of gravelly sands, while the lower and middle part of the Middle Pleistocene is composed of sands, with silts and clays discovered in the upper part. The Late Pleistocene is characterized by frequent lateral changes in gravels, sands, silts and clays, while the Holocene is generally composed of gravels and sands (VELIĆ \& DURN, 1993). Hydrogeologically, the Zagreb aquifer system is divided into three main units (Figs. 2 and 3). The first unit is overburden, which is in the most part disintegrated by anthropogenic influences. The thickness of this unit generally varies from 2 to 8 m (RUŽIČIĆ et al., 2012). Generally, Fluvisols, Stagnic Podzoluvisols and Eutric Cambisols are developed in the research area (SOLLITTO et al., 2010). The second unit is represented by the shallowest Holocene aquifer composed mostly of gravels and sands. The third unit is the deeper Pleistocene aquifer characterized by frequent lateral and vertical alternations of sand, gravel and clays (NAKIĆ et al., 2013). The thickness of the Holocene aquifer varies from 5 to $40 \mathrm{~m}$, while the deeper aquifer extends up to $60 \mathrm{~m}$ depth in the eastern area (NAKIĆ et al., 2011). Even though these aquifer layers are hydraulically connected, geochemical stratification with depth is recognized. Groundwater from the Holocene aquifer generally belongs to a $\mathrm{CaMg}-\mathrm{HCO}_{3}$ type while the Pleistocene aquifer can be additionally characterized by $\mathrm{CaMgNa}-\mathrm{HCO}_{3}$ hydrogeochemical facies. Higher sodium concentrations in groundwater can also be a consequence of anthropogenic influence in some areas (VLAHOVIĆ et al., 2009; MARKOVIĆ et al., 2013).

The Holocene aquifer is an unconfined aquifer. It is in direct contact with the Sava River, while the general groundwater flow is from $\mathrm{W} / \mathrm{NW}$ to $\mathrm{E} / \mathrm{SE}$. The Sava River represents the main source of recharge and the main boundary condition. POSAVEC (2006) showed that during medium and low water levels, the Sava River drains the aquifer in some areas, while during high water levels it gives water to the aquifer. This means that groundwater levels and the thickness of the unsaturated zone mainly depend on the Sava River, which significantly contributes to groundwater recharge in the study area (MILETIĆ \& BAČANI, 1999).

Industrial development and fast growth of the City of Zagreb have affected the groundwater quality in the research area. NAKIĆ et al. (2013) have identified pesticides, nitrates, potentially toxic metals, pharmaceuticals and chlorinated aliphatics as the main contaminants. Leakage from septic tanks, sewage systems and agricultural activity present the main potential sources of nitrate contamination in the Zagreb aquifer area. Nitrate trends are generally decreasing except in the eastern part on the left bank of the Sava River (NAKIĆ et al., 2016). It has been noted that threshold values, calculated with a VB macro BACKGROUND (NAKIĆ et al., 2007), of nitrate concentrations in groundwater of the wider Zagreb area generally range from 7.6 to $18.9 \mathrm{mg} / \mathrm{l}$ (NAKIĆ et al., 2010; KOVAČ et al., 2013; NAKIĆ et al., 2016), depending on the hydrological conditions in which they were calculated. Those concentrations suggest existence of 


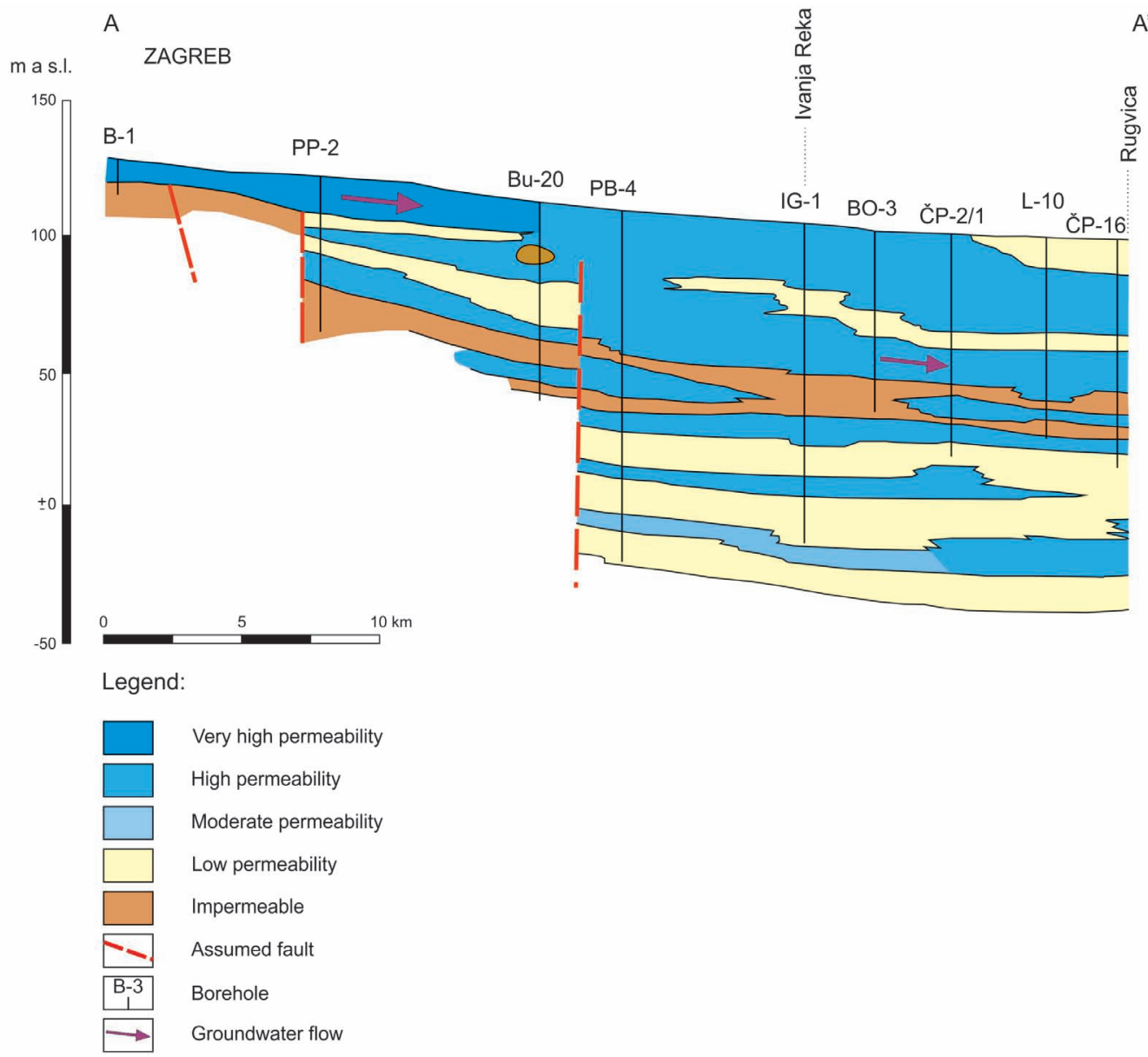

Figure 2. A schematic longitudinal hydrogeological profile across the study area (modified according to BRKIĆ, 1999).

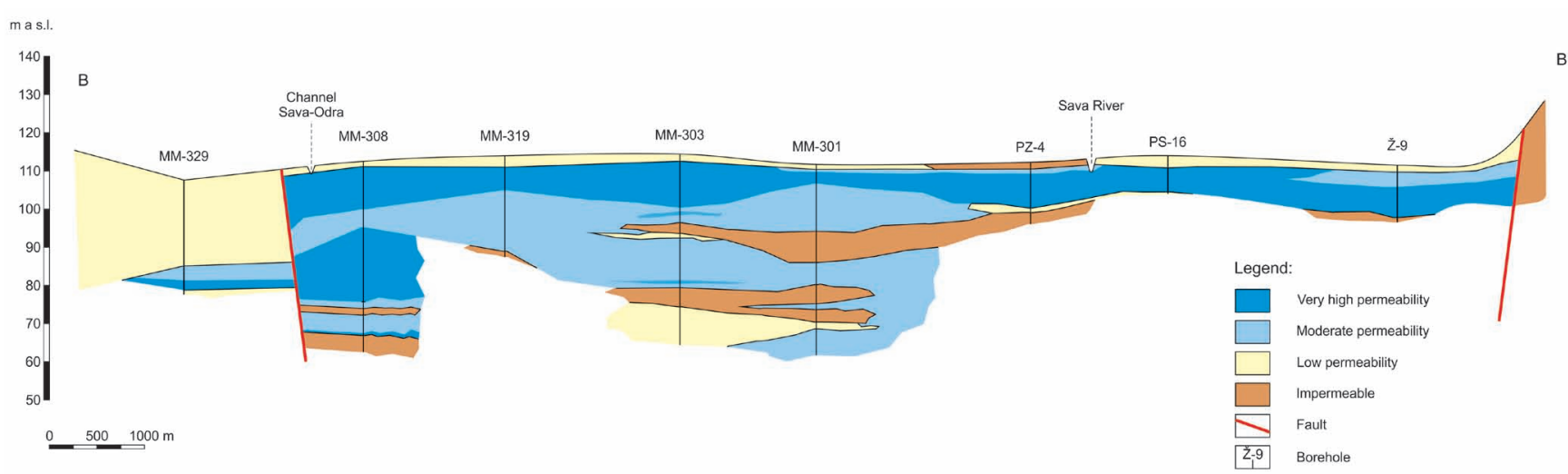

Figure 3. Schematic cross section hydrogeological profile (modified according to NAKIĆ et al., 2016).

very high ambient background nitrate concentrations in the study area which represents direct evidence of anthropogenic influence on the groundwater quality of the Zagreb aquifer. Also, groundwater levels are declining, on average, for 1-2 metres every ten years, while the permanent groundwater reserves have decreased for about 4\% from 1976 to 2006 (BAČANI et al., 2010). The main reasons for groundwater decrease are associated with the deepening of the Sava riverbed, increased groundwater abstraction and construction of dykes along the Sava River (POSAVEC, 2006).

\section{DATA AND METHODS}

Groundwater quality data from 1991 to 2015 were used for this research. They originate from 153 observation wells of the Na- tional Monitoring Programme of Croatian Waters and the monitoring programme of the Jakuševec landfill. It has been noted that some observation wells were used in the monitoring programme for only a few years, after which they were excluded. Also, different sampling intervals have been observed, from monthly to yearly. Therefore, given the sampling interval variation and inconsistent exclusion and inclusion of some observation wells from the monitoring network through observed time period, the data were aggregated at the level of a given observation well. Average values were calculated for all the observed parameters $\left(\mathrm{NO}_{3}{ }^{-}, \mathrm{O}_{2}, \mathrm{ORP}, \mathrm{pH}, \mathrm{EC}\right.$ and temperature of groundwater) for each observation well. All values below the limit of quantification for nitrate were not taken into account (237 values of $\mathrm{NO}_{3}{ }^{-}$in 


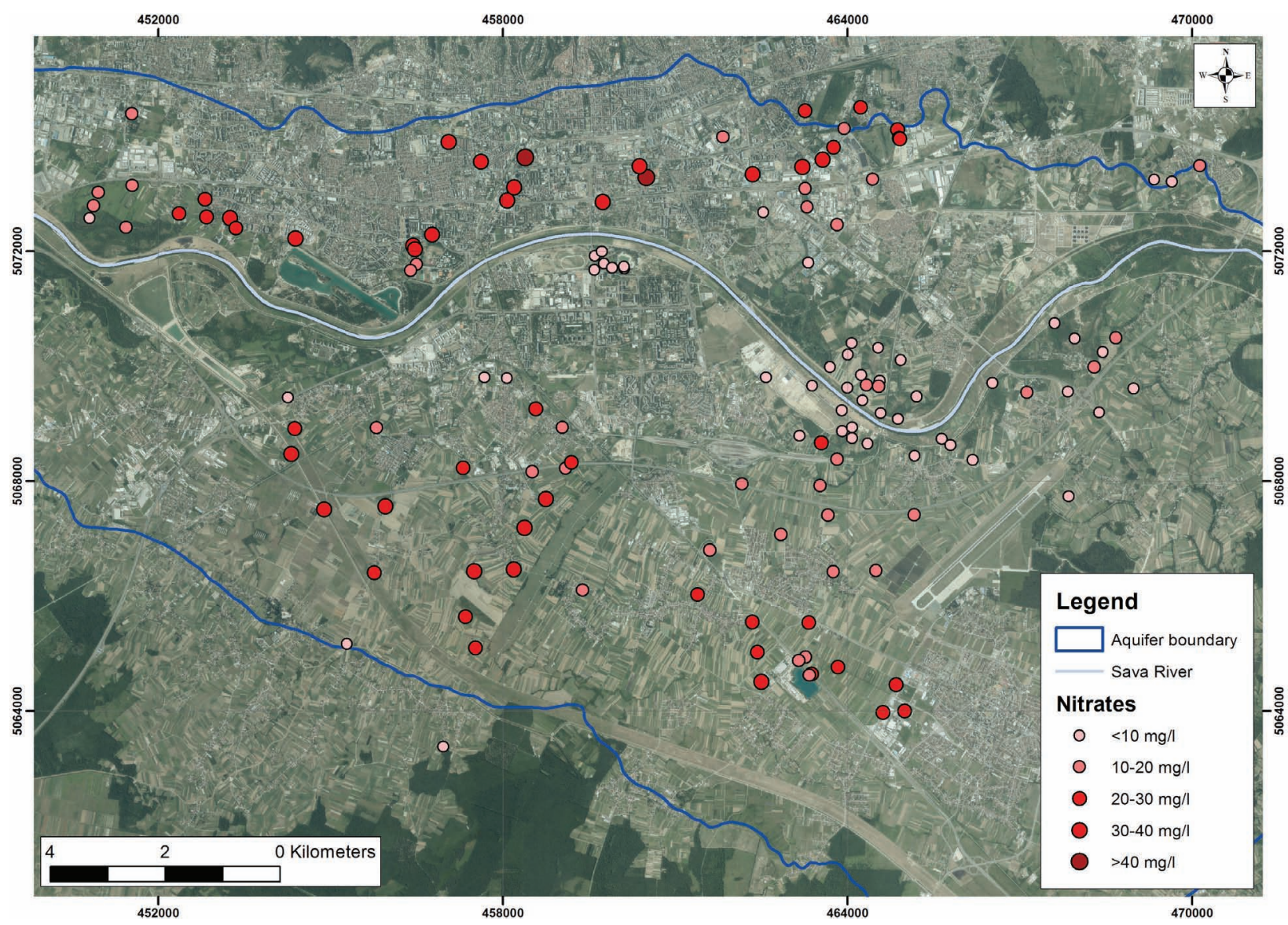

Figure 4. Average nitrate concentration.

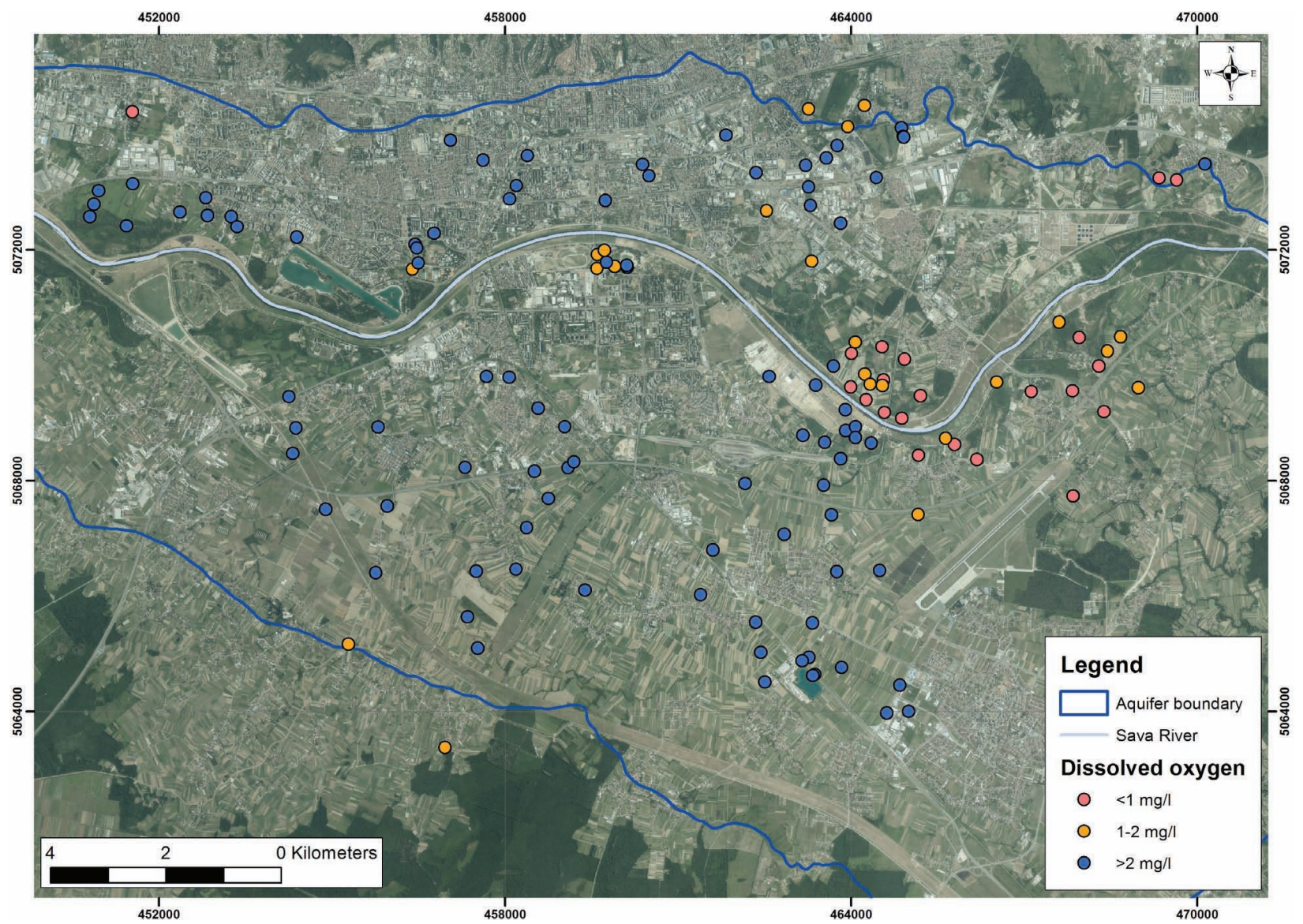

Figure 5. Average dissolved oxygen concentration. 
about 16000 analysis, i.e. $\sim 1.5 \%$ of values). Due to the lack of ORP data for some observation wells, statistical analyses were done using data from just 126 observation wells. A normal distribution of selected variables was tested by the KolmogorovSmirnov test ( $D$-calculated value; $D_{0}$-critical value based on number of cases; $\alpha=0.05$ ), using Statistica 64 (version 13.1) software. All data were standardized to Z-scores. Nitrate concentrations from three river stations (Jankomir, Petruševec and Rugvica, Fig. 1) were compared to the nitrate groundwater concentrations.

Pearson $r$ and Spearman $\rho$ correlation coefficients were calculated for all the observed parameters. Parametric and nonparametric correlation coefficients were used due to differences in the normal distribution of the selected parameters. There are different classifications concerning the interpretation of correlation coefficients. For example, UDOVIČIĆ et al. (2007) stated that correlations coefficients values from 0 to \pm 0.25 indicate absence of correlation, values from \pm 0.25 to \pm 0.50 indicate poor correlation, values from \pm 0.50 to \pm 0.75 indicate moderate to good correlation and values from \pm 0.75 to \pm 1 indicate very good to excellent correlation. The statistical significance of correlation coefficients was calculated using a $t$-test $(\alpha=0.05)$, using Statistica 64 software. Principal component analysis (default extraction method under factor analysis in Statistica 64) was used to identify the principal components (PC) and variables that create them. Varimax rotation was used for interpretation of final loadings due to its general successful applicability (HAIR et al., 2010). Cluster analysis was then performed using only those variables that had loadings $> \pm 0.5$ (which is consistent with guidelines provided in HAIR et al. (2010)), and were in the same principal component with nitrates. The purpose of cluster analysis was to group observation wells based on variables obtained from principal component analysis. For those purposes cluster analysis was tested using Ward's method, single linkage and complete linkage rules, while Euclidean and squared Euclidean distances were used as distance measures. Even though there are different rules of thumb that prescribe the minimal requirement of sample size for factor analysis, a minimum of 100 cases (MACCALLUM et al., 1999) and a case/variable ratio of 5:1 (BRYANT \& YARNOLD, 1995; HAIR et al., 2010) rule was satisfied. Regarding usage of minimal sample size in cluster analysis, MOOI \& SARSTEDT (2011) stated that there is no general rule of thumb that provides minimum sample size, or the relationship between the cases and number of clustering variables. In the end, all available $\mathrm{pH}$ and ORP data were placed on a Pourbaix diagram for nitrogen compounds, which shows the possible stable equilibrium phases of an aqueous electrochemical system. For this purpose 3202 pairs of $\mathrm{pH}$ and ORP values available from groundwater chemical analyses were used. Calculations and figure construction was done using Microsoft ${ }^{\odot}$ Excel, Statistica 64 (version 13.1) and ArcMap 10.1, while a geocoded terrain (georeferenced orthophoto) image was obtained from the geoportal of the Croatian Geodetic Administration. All maps are presented using the official coordinate system of the Republic of Croatia (HTRS96/TM).

\section{RESULTS AND DISCUSSION}

\subsection{Average values of observed variables}

Average nitrate concentrations from 153 observation wells are shown in Fig. 4. They vary from 0.8 to $44.20 \mathrm{mgl}^{-1} \mathrm{NO}_{3}{ }^{-}$. The highest concentrations are registered in groundwater of the urban part of the City of Zagreb (the left bank of the Sava River) and in the predominantly agricultural area between Mala Mlaka and Velika Gorica City (the right bank of the Sava River). Dissolved oxygen concentrations are shown in Fig. 5 and are divided into 3 groups $\left(<1,1-2\right.$ and $\left.>2 \mathrm{mgl}^{-1}\right)$. Dissolved oxygen concentrations were divided into 3 groups to identify observation wells with predominantly aerobic conditions $\left(>2 \mathrm{mgl}^{-1}\right)$, predominantly anaerobic conditions $\left(<1 \mathrm{mgl}^{-1}\right)$, and those that have threshold values between the two types of conditions $\left(1-2 \mathrm{mgl}^{-1}\right)$. It can be seen that predominantly aerobic conditions prevail in the western part of the aquifer system, while more anaerobic conditions occur in the eastern part of the aquifer system and in some observation wells that are located in the vicinity of the Sava River. Observation wells that have dissolved oxygen concentrations between 1 and $2 \mathrm{mgl}^{-1}$ only occur in the eastern part, near the Sava River. Average ORP values vary from 48.82 to $524.89 \mathrm{mV}$, while $\mathrm{pH}$ values vary from 6.98 to 7.63 . EC ranges from 425.28 to 1241.4 $\mu \mathrm{S} / \mathrm{cm}$, where the higher values are mostly located on the left bank of the Sava River, in the urban part of the City of Zagreb. Water temperature varies on average from 11.4 to $17^{\circ} \mathrm{C}$.

\subsection{Correlation}

Results of the Kolmogorov-Smirnov test are shown in Table 1. Results show that ORP and temperature of groundwater are not normally distributed, while $\mathrm{NO}_{3}{ }^{-}, \mathrm{O}_{2}, \mathrm{pH}$ and $\mathrm{EC}$ show normal distribution patterns.

Correlation coefficient matrices for $r$ and $\rho$ are shown in Table 2 . All statistically significant results are marked in red. Generally, the results show that nitrate concentrations are more related to $\mathrm{pH}, \mathrm{O}_{2}$ and $\mathrm{EC}$, where correlation with $\mathrm{pH}$ is negative, while correlation with the other two parameters is positive. Positive correlations of $\mathrm{NO}_{3}{ }^{-}$with $\mathrm{O}_{2}$ and $\mathrm{EC}$ seem very logical because higher $\mathrm{O}_{2}$ concentrations should provide a more stable geochemical

Table 1. Results of Kolmogorov-Smirnov test.

\begin{tabular}{lcccc}
\hline Variable & $\mathrm{D}$ & $\mathrm{D}_{0}$ & $\mathrm{~N}$ & Normal distribution \\
\hline $\mathrm{NO}_{3}{ }^{-}$ & 0.117 & 0.121 & 126 & YES \\
\hline $\mathrm{ORP}$ & 0.200 & 0.121 & 126 & NO \\
\hline $\mathrm{O}_{2}$ & 0.092 & 0.121 & 126 & YES \\
\hline $\mathrm{pH}$ & 0.096 & 0.121 & 126 & YES \\
\hline EC & 0.094 & 0.121 & 126 & YES \\
\hline Temperature & 0.137 & 0.121 & 126 & NO \\
\hline
\end{tabular}

Table 2. Pearson and Spearman correlation matrix.

\begin{tabular}{lcccccc}
\hline Pearson & & & & & \\
\hline Parameter & Temperature & $\mathrm{pH}$ & $\mathrm{ORP}$ & $\mathrm{O}_{2}$ & $\mathrm{EC}$ & $\mathrm{NO}_{3}{ }^{-}$ \\
\hline Temperature & 1.00 & & & & & \\
\hline $\mathrm{pH}$ & -0.13 & 1.00 & & & & \\
\hline $\mathrm{ORP}$ & -0.15 & 0.24 & 1.00 & & & \\
\hline $\mathrm{O}_{2}$ & -0.32 & -0.60 & -0.05 & 1.00 & & \\
\hline $\mathrm{EC}$ & 0.21 & -0.95 & -0.28 & 0.51 & 1.00 & \\
\hline $\mathrm{NO}_{3}{ }^{-}$ & 0.06 & -0.74 & -0.13 & 0.74 & 0.76 & 1.00 \\
\hline $\mathrm{Spearman}^{-}$ & & & & & & \\
\hline Parameter & Temperature & $\mathrm{pH}$ & $\mathrm{ORP}$ & $\mathrm{O}_{2}$ & $\mathrm{EC}$ & $\mathrm{NO}_{3}{ }^{-}$ \\
\hline Temperature & 1.00 & & & & & \\
\hline $\mathrm{pH}^{-0.16}$ & 1.00 & & & & \\
\hline $\mathrm{ORP}^{-0.15}$ & 0.24 & 1.00 & & & \\
\hline $\mathrm{O}_{2}$ & -0.37 & -0.56 & -0.02 & 1.00 & & \\
\hline $\mathrm{EC}$ & 0.17 & -0.97 & -0.27 & 0.54 & 1.00 & \\
\hline $\mathrm{NO}_{3}{ }^{-}$ & -0.05 & -0.76 & -0.07 & 0.76 & 0.78 & 1.00 \\
\hline
\end{tabular}




\begin{tabular}{lcccccc} 
Variable & \multicolumn{2}{l}{ Varimax rotation } & \multicolumn{4}{l}{ Communalities } \\
\cline { 2 - 7 } & $\mathrm{PC} \mathrm{1}$ & $\mathrm{PC} 2$ & From 1 PC & From 2 PC & $\begin{array}{c}\text { Multiple } \\
\mathrm{R} \text {-Square }\end{array}$ \\
\cline { 2 - 7 } & 0.04 & -0.87 & 0.00 & 0.75 & 0.33 \\
\hline $\mathrm{PH}$ & -0.93 & 0.13 & 0.87 & 0.89 & 0.93 \\
\hline $\mathrm{ORP}$ & -0.28 & 0.51 & 0.08 & 0.34 & 0.11 \\
\hline $\mathrm{O}_{2}$ & 0.78 & 0.49 & 0.61 & 0.84 & 0.74 \\
\hline $\mathrm{EC}^{2}$ & 0.92 & -0.24 & 0.85 & 0.90 & 0.93 \\
\hline $\mathrm{NO}_{3}{ }^{-}$ & 0.91 & 0.08 & 0.82 & 0.83 & 0.78
\end{tabular}

environment for nitrates, while higher EC values are generally associated with higher human impact, resulting in higher concentrations of dissolved substances, including higher $\mathrm{NO}_{3}{ }^{-}$concentrations. $\mathrm{pH}$ is negatively correlated with $\mathrm{O}_{2}, \mathrm{EC}$ and $\mathrm{NO}_{3}{ }^{-}$. ORP values show no or very poor correlation with all other variables, as well as with the groundwater temperature. Usually it is suggested that Pearson correlation coefficient shoudn't be used when variables are not normally distributed. It has to be stressed that both Pearson and Spearman correlation statistics for ORP and groundwater temperature are very similar indicating that in some cases Pearson correlation coefficient can be used although all variables don't follow the normal distribution. It is obvious that the Pearson correlation coefficient can be used when only one variable has a normal distribution and when a sufficiently large data size is available, which is consistent with recommendations provided by UDOVIČIĆ et al. (2007).

\subsection{Principal component analysis}

Principal component analysis generated 2 principal components explaining $76 \%$ of the total variance, where $54 \%$ was explained by the first component. Varimax raw rotated loadings are shown in Table 3, together with its communalities. PC 1 is presented with $\mathrm{pH}, \mathrm{O}_{2}, \mathrm{EC}$ and $\mathrm{NO}_{3}{ }^{-}$, while $\mathrm{PC} 2$ is presented with groundwater temperature and ORP. It is evident that an oxygenated environment generates higher nitrate concentrations and $\mathrm{EC}$ values which results in a more acidic environment. Also, results indicate that the ORP and temperature of groundwater are not related to nitrate concentrations, which coincides with previous results. Furthermore, results suggest that ORP and groundwater temperature present variables that are less under human influence than the variables from PC 1. Due to very low communalities of ORP $(<0.5)$ and the affiliation of the temperature of groundwater to different principal components, these two variables were excluded from the cluster analysis. Varimax rotation loadings are shown in Fig 6.

\subsection{Cluster analysis}

Cluster analysis was performed using three different methods, where Ward 's method generated the two most distinctive clusters (Fig. 7 and 8). In all cases squared Euclidean distances and Euclidean distances gave similar results. However, the squared distances facilitated the drawing of conclusions regarding the number of clusters.

The results of cluster analysis obtained using Ward 's method have been taken as the most representative one, which is probably a consequence of Ward's method of calculation. Single and linkage methods define the similarity of clusters using minimum and maximum distances between objects, while Ward's methods maximizes the homogeneity between clusters using the sum of squares within the cluster. Evaluation of projected clusters have shown two main results. First, clusters have very distinctive concentrations of $\mathrm{NO}_{3}{ }^{-}, \mathrm{O}_{2}$ and $\mathrm{EC}$ (Table 4). Cluster 1 has generally lower values of variables, while cluster 2 has higher values. In cluster 1 the average value of $\mathrm{O}_{2}$ from 61 observation wells is 1.77 $\mathrm{mgl}^{-1}$, of EC is $573.31 \mu \mathrm{S} / \mathrm{cm}$, and of $\mathrm{NO}_{3}{ }^{-}$is $7.84 \mathrm{mgl}^{-1}$. In cluster 2 the average value of $\mathrm{O}_{2}$ from 65 observation wells is $4.8 \mathrm{mgl}^{-1}$,

\section{Principal component Loadings, PC 1 vs. PC 2 Rotation: Varimax raw Extraction: Principal components}

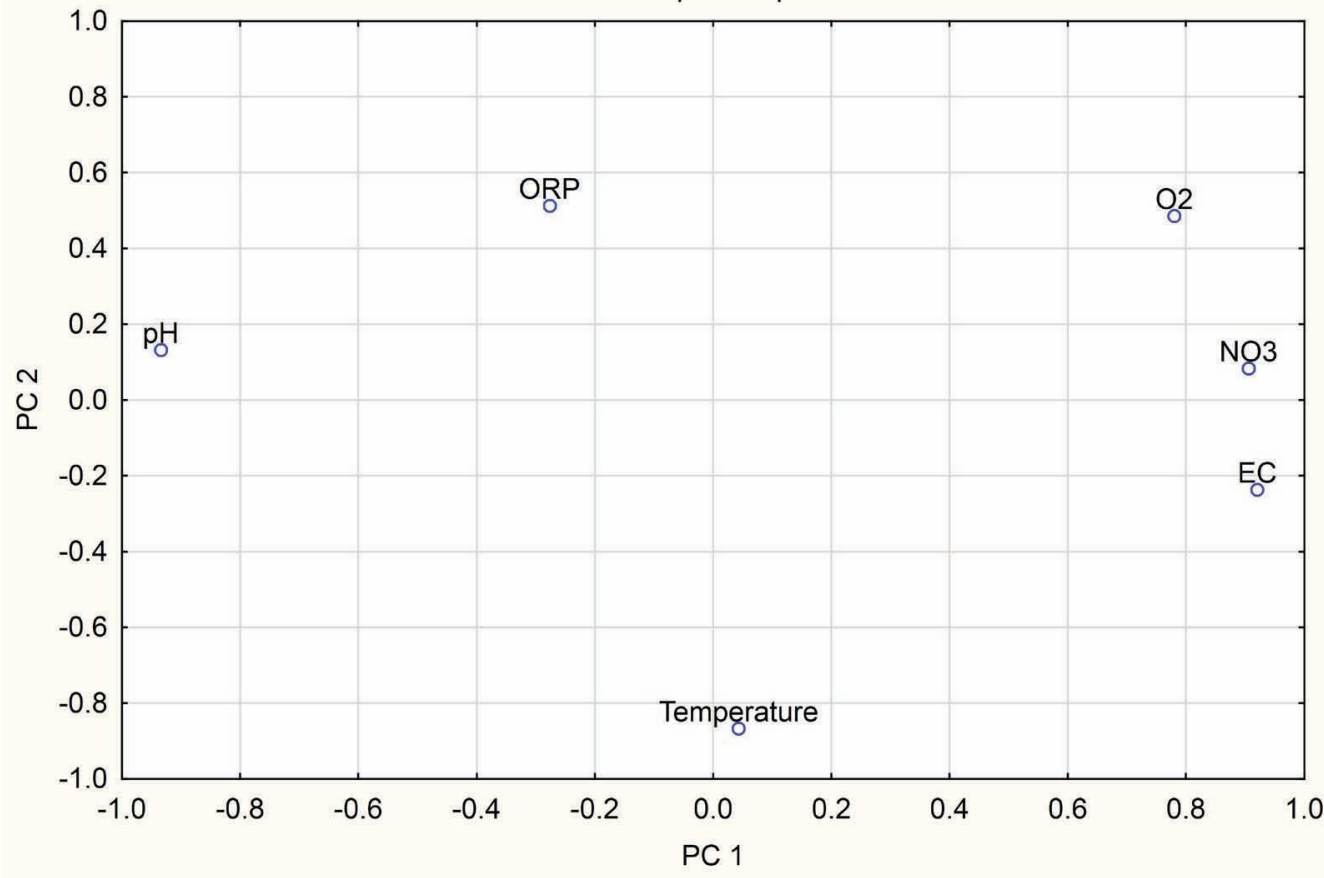

Figure 6. Varimax raw rotated variable loadings on PC 1 and PC 2. 
Tree Diagram for 126 Cases

Ward's method

Euclidean distances

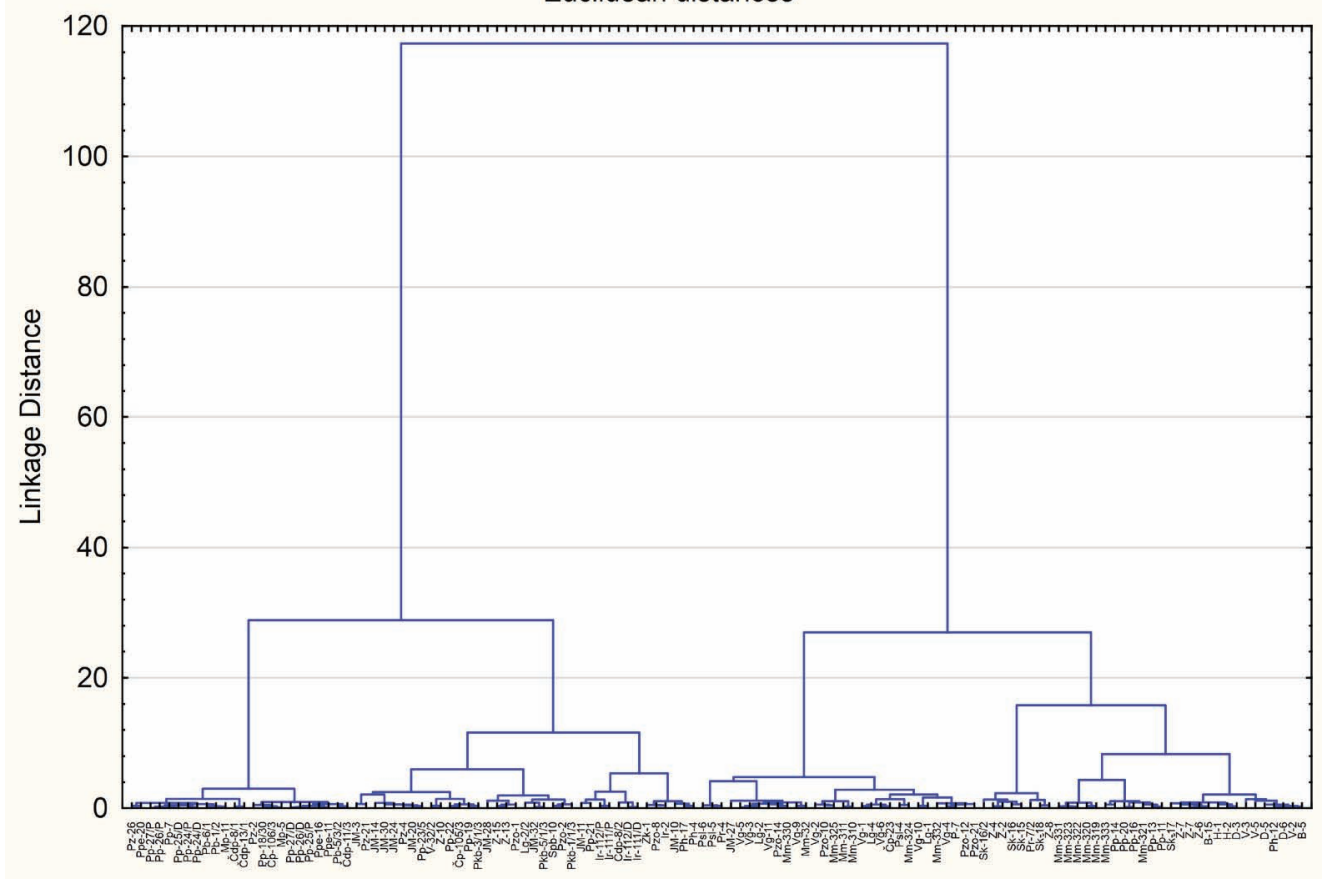

Figure 7. Tree diagram with Ward’s method (Euclidean distances).

of EC is $859.03 \mu \mathrm{S} / \mathrm{cm}$, and of $\mathrm{NO}_{3}{ }^{-}$is $25.93 \mathrm{mgl}^{-1}$. These results indicate that $\mathrm{NO}_{3}{ }^{-}$concentrations are generally controlled by $\mathrm{O}_{2}$ concentrations. Also, where higher concentrations of EC are recorded, higher nitrate concentrations can also be expected, which is also confirmed by correlation analysis. Secondly, if clusters are evaluated spatially (Fig. 9), observation wells in different clusters generally coincide with the average values of dissolved oxygen shown in Fig. 3. Most of the observation wells from cluster 1 are near the Sava River, in the area with the lower oxygen content. Nitrate concentrations in the Sava River have average concentrations of $7.33 \mathrm{mgl}^{-1}$ at the Jankomir station, $7.5 \mathrm{mgl}^{-1}$ at the Petruševec, and $6.67 \mathrm{mgl}^{-1}$ at Rugvica (Table 5), while the ave-

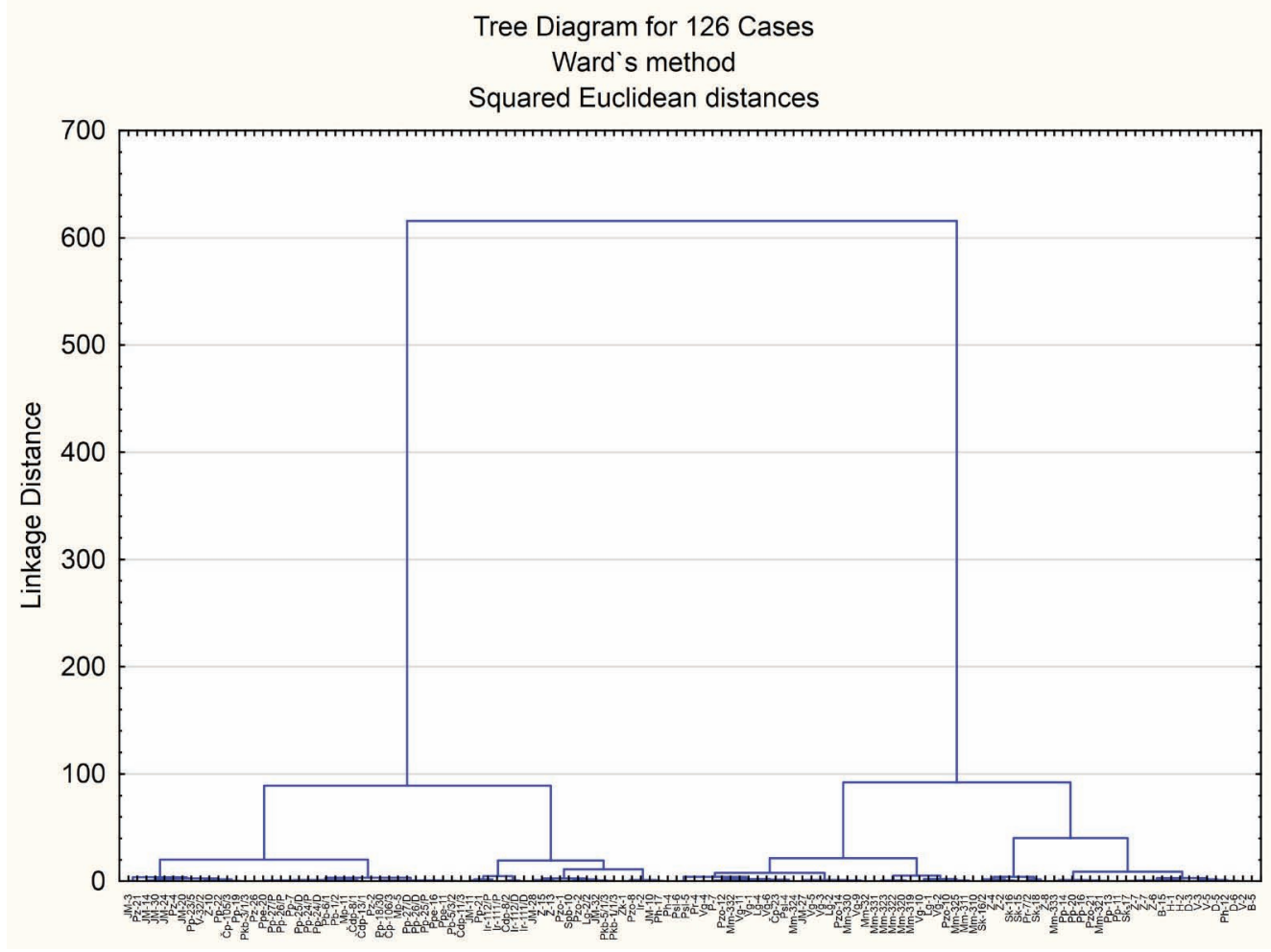

Figure 8. Tree diagram with Ward`s method (Squared Euclidean distances). 


\begin{tabular}{|c|c|c|c|c|c|c|c|c|}
\hline Variable & & $\begin{array}{c}\text { Number of } \\
\text { observation wells }\end{array}$ & Temperature $\left({ }^{\circ} \mathrm{C}\right)$ & $\mathrm{pH}$ & $\mathrm{ORP}(\mathrm{mV})$ & $\mathrm{O}_{2}(\mathrm{mg} / \mathrm{l})$ & $\mathrm{EC}(\mu \mathrm{S} / \mathrm{cm})$ & $\mathrm{NO}_{3}{ }^{-}(\mathrm{mg} / \mathrm{l})$ \\
\hline \multirow{3}{*}{ Cluster 1} & Average & & 13.66 & 7.38 & 254.30 & 1.77 & 573.31 & 7.84 \\
\hline & Minimum & 61 & 11.58 & 7.10 & 48.83 & 0.21 & 425.28 & 0.57 \\
\hline & Maximum & & 17.02 & 7.63 & 524.89 & 5.63 & 871.86 & 26.36 \\
\hline \multirow{3}{*}{ Cluster 2} & Average & & 13.50 & 7.14 & 234.27 & 4.80 & 859.03 & 25.93 \\
\hline & Minimum & 65 & 11.43 & 6.98 & 134.00 & 0.69 & 451.83 & 6.26 \\
\hline & Maximum & & 15.59 & 7.53 & 477.24 & 7.53 & 1241.40 & 44.20 \\
\hline
\end{tabular}

rage $\mathrm{NO}_{3}{ }^{-}$concentrations in cluster 1 are similar, i.e. $7.84 \mathrm{mgl}^{-1}$. Lower values of $\mathrm{O}_{2}$ in the eastern part of the Zagreb aquifer system are probably a consequence of greater aquifer depth and mixing of different groundwaters from Holocene (more oxidative condition) and Pleistocene aquifers (more reductive condition). Also, results indicate that the Sava River has an influence on the dissolved oxygen concentrations. The reasons for this could be varied. They can be associated with too many bacteria and an excess amount of biological oxygen demand, and maybe with fertilizer runoff from farm fields. The first reason is the more likely in this case because it can be associated with some kind of organic discharge, probably sewage. These results indicate that the quality of the Sava River is under very significant anthropogenic influences.

\subsection{Pourbaix diagram and dominant nitrogen species}

In general, all statistical analyses showed the close relationship of $\mathrm{NO}_{3}{ }^{-}, \mathrm{O}_{2}, \mathrm{EC}$ and $\mathrm{pH}$. ORP and groundwater temperature showed a very poor relationship with the other variables. When
Table 5. Average, minimum and maximum values of nitrate in the Sava River.

\begin{tabular}{lcc}
\hline Station & Parameter & $\mathrm{NO}_{3}{ }^{-}(\mathrm{mg} / \mathrm{l})$ \\
\hline \multirow{3}{*}{ Jankomir } & Average & 7.33 \\
& Minimum & 1.33 \\
& Maximum & 27.01 \\
\hline \multirow{2}{*}{ Petruševec } & Average & 7.5 \\
& Minimum & 1.77 \\
& Maximum & 25.67 \\
Rugvica & Average & 6.67 \\
& Minimum & 3.94 \\
\hline
\end{tabular}

evaluating the Pourbaix diagram for nitrogen species and measured data (Fig. 9) in the Zagreb aquifer, it can be seen that all values are oriented more in a vertical than in a horizontal direction. This indicates constant change in oxidative and reductive conditions in the Zagreb aquifer, which is also probably the reason why the correlation between $\mathrm{NO}_{3}{ }^{-}$and ORP can't be ob-

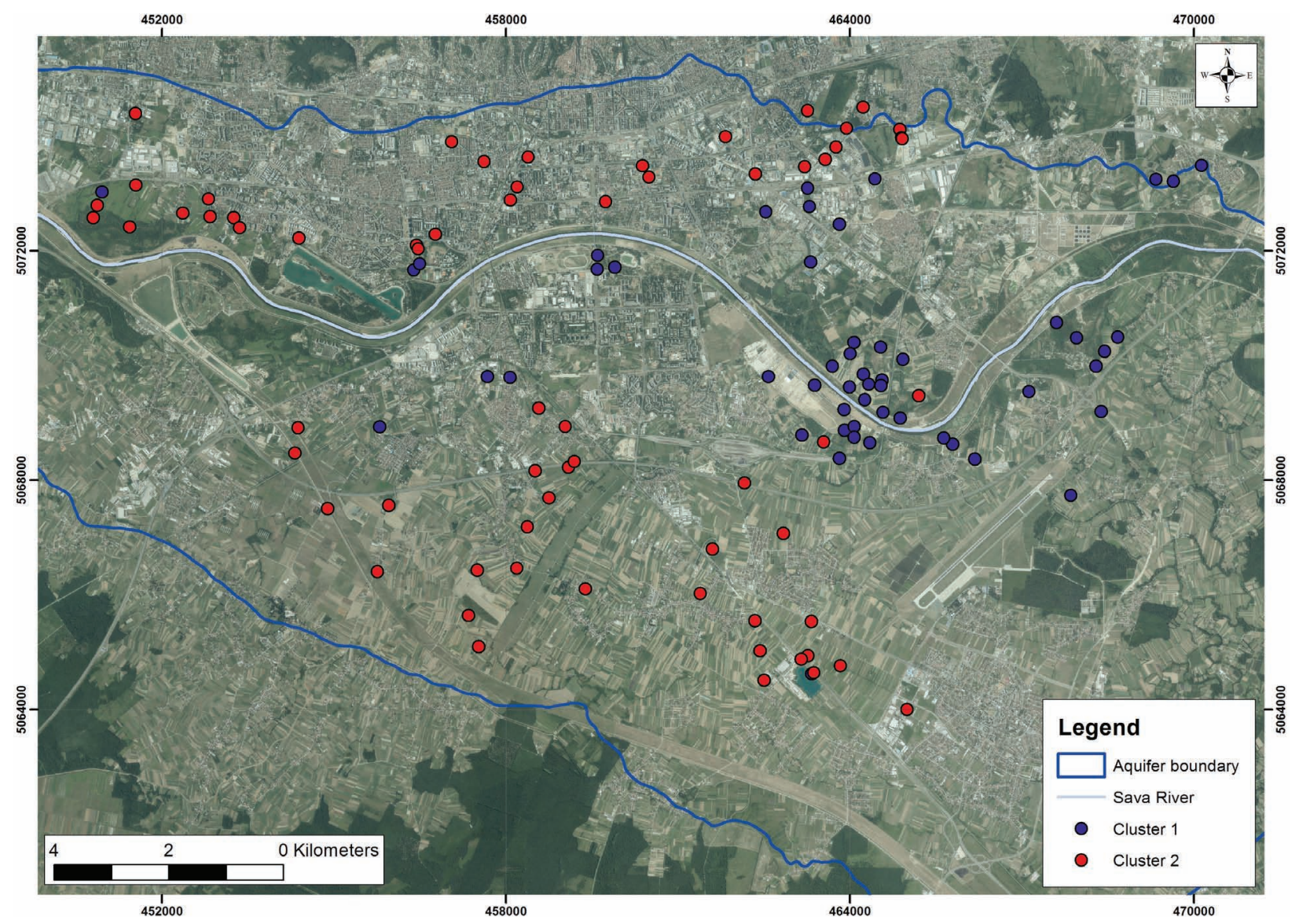

Figure 9. Clusters of observation wells with similar characteristics. 


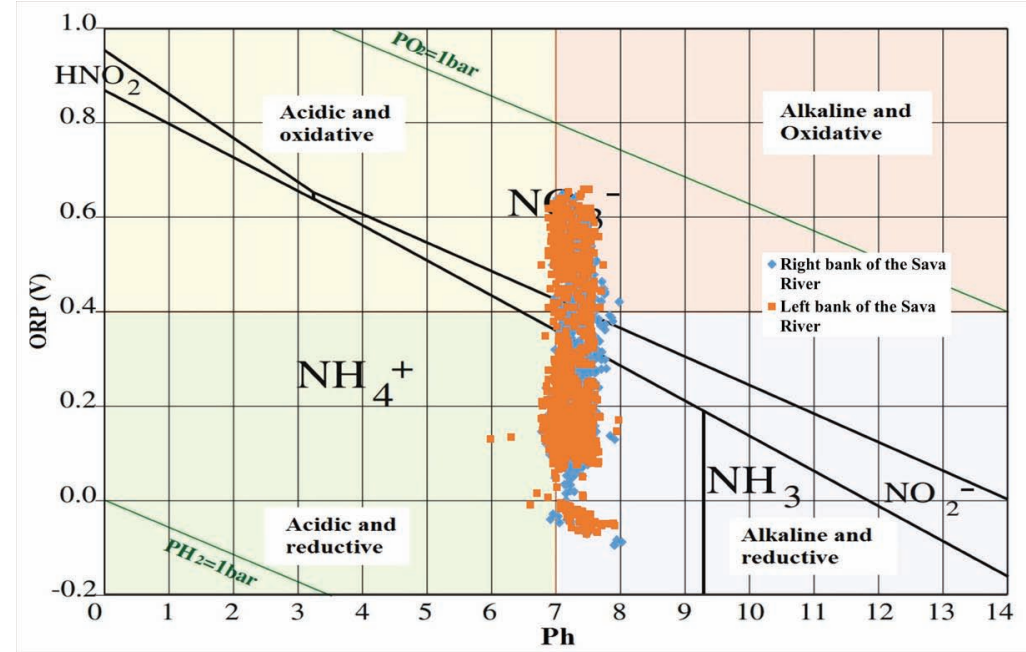

Figure 10. Pourbaix diagram for nitrogen species at Zagreb aquifer (background picture modified according to PUIGDOMENECH, 2006; HUSSON, 2013).

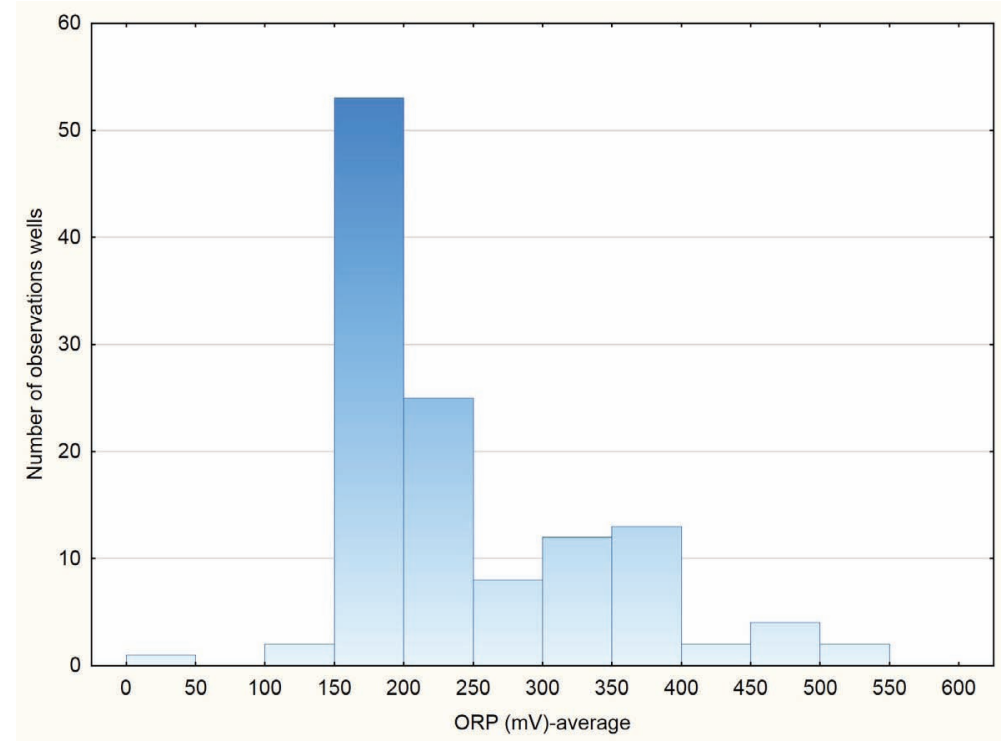

Figure 11. Histogram of average ORP values at Zagreb aquifer.

served. In Fig. 10 it can be seen that the most frequent average ORP class is that between 150 and $200 \mathrm{mV}$, which presents the threshold class between oxidative and reductive conditions in the aquifer (DIMKIĆ et al., 2008). Also, Fig. 10 shows that about $50 \%$ of observation wells have ORP values higher than $200 \mathrm{mV}$, which suggests that in the Zagreb aquifer system moderately oxi-
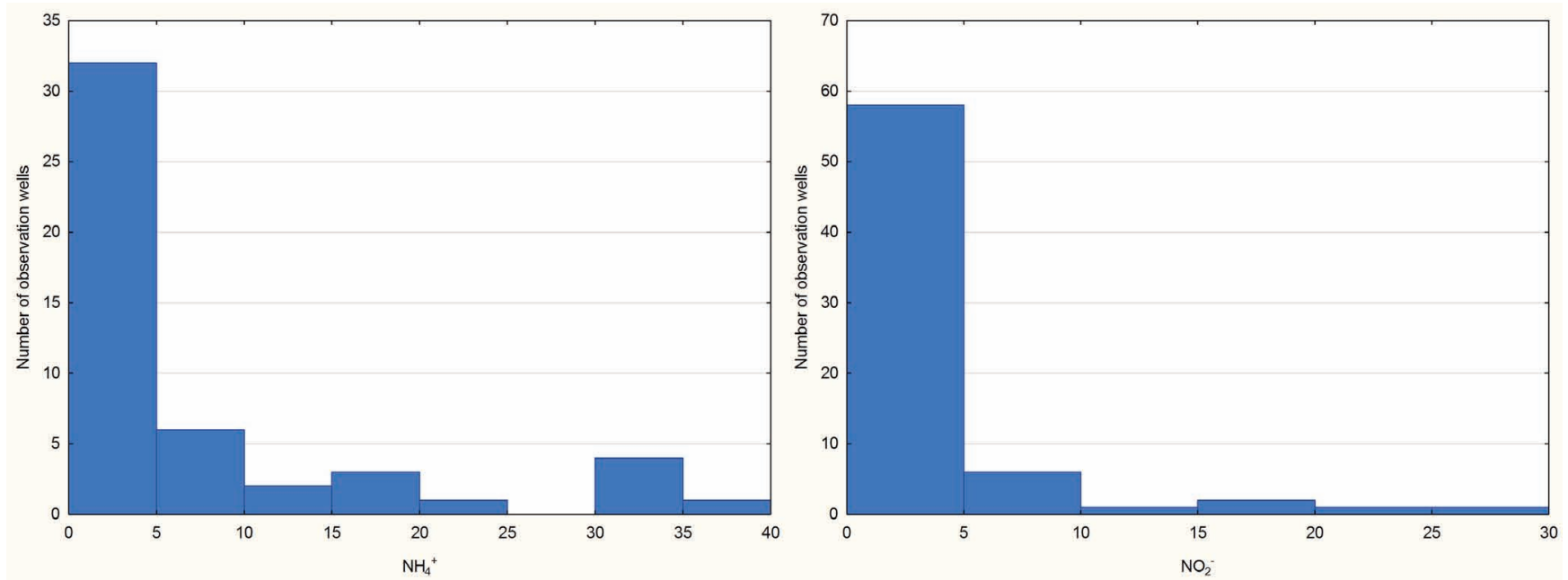

Figure 12. Occurrence of $\mathrm{NH}_{4}{ }^{+}$and $\mathrm{NO}_{2}{ }^{-}$concentrations in Zagreb aquifer from 1991 to 2015. 
dative conditions prevail. Furthermore, from Fig. 11 it can be seen that many samples fall in the area of high $\mathrm{NH}_{4}^{+}$stability. Due to the very rare occurrence of $\mathrm{NH}_{4}{ }^{+}$(367 values at 49 observation wells) and $\mathrm{NO}_{2}{ }^{-}$concentrations (249 values at 69 observation wells) observed in 25 years of groundwater quality monitoring of the Zagreb aquifer system (Fig. 12), it can be assumed that very rapid nitrification of $\mathrm{NH}_{4}{ }^{+}$and $\mathrm{NO}_{2}{ }^{-}$to $\mathrm{NO}_{3}{ }^{-}$occurs in the aquifer system. Moreover, Fig. 12 shows that concentrations of $\mathrm{NH}_{4}{ }^{+}$and $\mathrm{NO}_{2}{ }^{-}$on most observation wells occur less than five times in the observed period.

\section{CONCLUSION}

Nitrates represent one of the main groups of contaminants in the Zagreb aquifer system. Their concentrations are mainly the result of anthropogenic influences. Despite this, some natural groundwater quality indicators, more or less influenced by humans, may affect their stability and mobility in groundwater. Average values of $\mathrm{NO}_{3}{ }^{-}, \mathrm{O}_{2}, \mathrm{ORP}, \mathrm{pH}, \mathrm{EC}$ and the temperature of groundwater were used to test their relationship using correlation and multivariate statistical analysis. Pearson and Spearman correlation statistics have produced similar results in that $\mathrm{NO}_{3}{ }^{-}$is generally positively correlated with $\mathrm{O}_{2}$ and $\mathrm{EC}$, and negatively with $\mathrm{pH}$. ORP values showed no to very poor correlation with all other variables, as well as with the temperature of groundwater. Correlation analysis indicated that only $\mathrm{O}_{2}, \mathrm{EC}$ and $\mathrm{pH}$ were variables related to nitrate, which was confirmed with multivariate statistical analysis results. PCA was used to identify principal components and variables which were then used as variables in the cluster analysis. It generated $2 \mathrm{PCs}$ where only $\mathrm{pH}, \mathrm{O}_{2}, \mathrm{EC}$ and $\mathrm{NO}_{3}{ }^{-}$from $\mathrm{PC} 1$, with factor loadings $> \pm 0.5$, were used in the cluster analysis. Cluster analysis was tested with Ward's method, single linkage and complete linkage rules, while Euclidean and squared Euclidean distances were used as distance measures. Different distance measures did not provide any significantly different results of the cluster analysis, but linkage rule methods did. Ward 's method generated two most distinctive clusters, probably because of the difference in calculation of the difference between clusters, and its results were used for the evaluation of two clusters. Clusters mostly differ in $\mathrm{O}_{2}, \mathrm{EC}$ and $\mathrm{NO}_{3}{ }^{-}$concentrations. In cluster 1 lower values of $\mathrm{NO}_{3}{ }^{-}$are probably a consequence of the influence of the Sava River and greater aquifer depth in the eastern part of the aquifer system, where mixing of anaerobic and aerobic water occurs. Due to the great variability of ORP in the study area and lack of $\mathrm{NH}_{4}{ }^{+}$and $\mathrm{NO}_{2}{ }^{-}$species in groundwater, it can be assumed that very rapid nitrification of $\mathrm{NH}_{4}{ }^{+}$and $\mathrm{NO}_{2}{ }^{-}$to $\mathrm{NO}_{3}{ }^{-}$occurs in the Zagreb aquifer system, particularly in the shallow Holocene aquifer.

\section{ACKNOWLEDGMENT}

Authors would like to thank Croatian Waters for the data obtained within the project „Groundwater trend and status assessment in the Pannonian part of Croatia" and to Zagreb holding (branch ZGOS) for the data obtained from monitoring program of landfill Jakuševec.

\section{REFERENCES}

ALLER, L., BENNETT, T. \& LEHR, J.H. (1987): DRASTIC: a standardized system for evaluating groundwater pollution potential using hydrogeologic settings. US EPA/600/2-87/035.

ALMASRI, M.N. (2003): Optimal management of nitrate contamination of ground water-- PhD Dissertation. Utah State University, Logan, Utah, 229 p.
ALMASRI, M.N. (2007): Nitrate contamination of groundwater: A conceptual management framework.- Environmental Impact Assessment Review, 27, 220-242. doi:10.1016/j.eiar.2006.11.002.

BAČANI, A., POSAVEC, K. \& PARLOV, J. (2010): Groundwater quantity in the Zagreb aquifer.- In: ZUBER, A., KANIA, J. \& KMIECIK, E. (eds.): XXXVIII IAH Congress Groundwater Quality Sustainability, Krakow, September 12-17, 2010, 87-92.

BRKIĆ, Ž. (1999): Napajanje aluvijalnih vodonosnika sjeverne Hrvatske kroz slabije propusne krovinske naslage [Alluvial aquifer recharge through semipermeable covering deposits in northern Croatia - in Croatian].- Unpubl. PhD Thesis, Faculty of Mining, Geology and Petroleum Engineering, University of Zagreb, Zagreb, $157 \mathrm{p}$.

BRYANT, F.B. \& YARNOLD, P.R. (1995): Principal components analysis and exploratory and confirmatory factor analysis.- In: GRIMM, L.G. \& YARNOLD, R.R. (eds.): Reading and understanding multivariate statistics, 99-136. Washington, DC: American Psychological Association.

CHOWDARY, V.M., RAO, N.H. \& SARMA, P.B.S. (2005): Decision support framework for assessment of non-point-source pollution of groundwater in large irrigation projects.- Agricultural Water Management, 75, 194-225, doi: 10.1016/j.agwat.2004.12.013.

DIMKIĆ, M.A., BRAUCH, H.J. \& KAVANAUGH, M. (2008): Groundwater management in large river basins.- IWA Publishing, Alliance House, Biddles Ltd, Norfolk, UK.

HAIR, JR., J.F., BLACK, W.C., BABIN, B.J. \& ANDERSON, R.E. (2010): Multivariate data analysis.- Seventh edition, Prentice Hall, Upper Saddle River, NJ 07458, $785 \mathrm{p}$.

HERNITZ, Z., KOVAČEVIĆ, S., VELIĆ, J. \& URLI, M. (1981): Primjer kompleksnih geološko-geofizičkih istraživanja kvartarnih naslaga u okolici Prevlake [An example of complex geological and geophysical explorations of Wuaternary deposits in the soroundings of Prevlaka - in Croatian].- Geološki vjesnik, 33, 11-34, Zagreb.

HOSONO, T., TOKUNAGA, T., KAGABU, M., NAKATA, H., ORISHIKIDA, T., LIN, I. \& SHIMADA, J. (2013): The use of $\delta^{15} \mathrm{~N}$ and $\delta^{18} \mathrm{O}$ tracers with an understanding of groundwater flow dynamics for evaluating the origins and attenuation mechanisms of nitrate pollution.- Water Research, 47, 2661-2675. doi:10.1016/j. watres.2013.02.020

HUSSON O. (2013): Redox potential (Eh) and $\mathrm{pH}$ as drivers of soil/plant/microorganism systems: a transdisciplinary overview pointing to integrative opportunities for agronomy.- Plant Soil, 362, 389-417. doi:10.1007/s11104-012-1429-7.

JEONG, C.H. (2001): Effect of land use and urbanization on hydrochemistry and contamination of groundwater from Taejon area, Korea.- Journal of Hydrology 253(1-4), 194-210. doi: 10.1016/S0022-1694(01)00481-4.

KOVAČ, Z., NAKIĆ, Z., POSAVEC, K., PARLOV, J. \& BAČANI, A. (2013): Ambient background concentrations of chemical parameters in groundwater of Samobor aquifer. Waters in sensitive and protected areas (ISBN: 978-953-96071-3-3), $163-166$.

KOVAC̆, Z., PAVLIĆ, K. \& NAKIĆ, Z. (2016): Influence of dissolved oxygen on nitrates concentration in Zagreb aquifer. $8^{\text {th }}$ Croatian-Hungarian and $19^{\text {th }}$ Hungarian geomathematical congress, Geomathematics - present and future of geological modelling, 89-96 (ISBN: 978-953-59036-1-1).

LAKE, I.R., LOVETT, A.A., HISCOCK, K.M., BETSON, M., FOLEY, A., SUNNENBERG, G., EVERS, S. \& FLETCHER, S. (2003): Evaluating factors influencing groundwater vulnerability to nitrate pollution: developing the potential of GIS.Journal of Environmental Management, 68, 315-328. doi: 10.1016/S03014797(03)00095-1

LARVA, O., MARKOVIĆ, T. \& BRKIĆ, Ž. (2010): Groundwater hydrochemistry of the quaternary alluvial aquifer in Varaždin region - Croatia. XXXVIII IAH Congress (ISSN: 0208-6336).- Groundwater Quality Sustainability, Krakow, 493-500.

LI, S.L, LIU, C.Q., LANG, Y.C., ZHAO, Z.Q. \& ZHOU, Z.H. (2010): Tracing the sources of nitrate in karstic groundwater in Zunyi, Southwest China: a combined nitrogen isotope and water chemistry approach.- Environmental Earth Sciences, 60, 1415-1423, doi: 10.1007/s12665-009-0277-0.

MACCALLUM, R.C., WIDAMAN, K.F., ZHANG, S. \& HONG, S. (1999): Sample size in factor analysis. Psychological Methods, 4, 84-99. doi: 10.1037/1082989X.4.1.84

MARKOVIĆ, T., BRKIĆ, Ž. \& LARVA, O. (2013): Using hydrochemical data and modelling to enhance the knowledge of groundwater flow and quality in an alluvial aquifer of Zagreb, Croatia.- Science of the Total Environment, 458-460, 508-516, doi: 10.1016/j.scitotenv.2013.04.013.

MILETIĆ, P. \& BAČANI, A. (1999): EGPV: Izrada bilansa [Development of water balance - in Croatian]. Book 4, $4^{\text {th }}$ part. Faculty of Mining, Geology and Petroleum Engineering, University of Zagreb, Zagreb.

MKANDAWIRE, T. (2008): Quality of groundwater from shallow wells of selected villages in Blantyre District, Malawi.- Physics and Chemistry of the Earth 33/(8-13). doi: 807-811, doi:10.1016/j.pce.2008.06.023.

MOOI, E. \& SARSTEDT, M. (2011): A Concise Guide to Market Research. The Process, Data, and Methods using IBM SPSS Statistics. ISBN: 978-3-642-12541-6, $307 \mathrm{p}$. 
MORATALLA, A., GÓMEZ-ALDAY, J.J. \& DE LAS HERAS, J. (2009): Nitrate in the Water-Supply Wells in the Mancha Oriental Hydrogeological System (SE Spain).Water Resources Management, 23/8, 1621-1640. doi: 10.1007/s11269-008-9344-7.

NAKIĆ, Z., RUŽIČIĆ, S., POSAVEC, K., MILEUSNIĆ, M., PARLOV, J., BAČANI, A. \& DURN, G. (2013): Conceptual model for groundwater status and risk assessment - case study of the Zagreb aquifer system.- Geologia Croatica, 66/1, doi: $10.4154 /$ GC.2013.05

NAKIĆ, Z., POSAVEC, K. \& BAČANI, A. (2007): A Visual Basic spreadsheet macro for geochemical background analysis.- Ground Water 45/5, 642-647. Print ISSN: 0017-467X, Online ISSN: 1745-6584. doi: 10.1111/j.1745-6584.2007.00325.x.

NAKIĆ, Z., POSAVEC, K. \& PARLOV, J. (2010): Model-based objective methods for the estimation of groundwater geochemical background. AQUAmundi 1, no. 1: 065-072. Print ISSN: 2038-3584, Online ISSN: 2038-3592.

NAKIĆ, Z., POSAVEC, K., PARLOV, J. \& BAČANI, A. (2011): Development of the Conceptual Model of the Zagreb Aquifer System. The Geology in Digital Age: Proceedings of the $17^{\text {th }}$ Meeting of the Association of European Geological Societies, MAEGS 17 / BANJAC, N. (ed.).- Belgrade: Serbian Geological Society, 2011. 169-174 (ISBN: 978-86-86053-10-7).

NAKIĆ, Z., BAČANI, A., PARLOV, J., DUIĆ, Ž., PERKOVIĆ, D., KOVAČ, Z., TUMARA, D., MIJATOVIĆ, I., ŠPOLJARIĆ, D., UGRINA, I., STANEK, D. \& SLAVINIĆ, P. (2016): Definiranje trendova i ocjena stanja podzemnih voda na području panonskog dijela Hrvatske [Groundwater trend and status assessment in the Pannonian part of Croatia - in Croatian].- Stručna studija, Rudarsko-geološkonaftni fakultet, Sveučilište u Zagrebu.

PEÑA-HARO, S., PULIDO-VELAZQUEZ, M. \& SAHUQUILLO, A. (2009): A hydroeconomic modelling framework for optimal management of groundwater nitrate pollution from agriculture.- Journal of Hydrology, 373, 193-203, doi: 10.1016/j. jhydrol.2009.04.024.

POSAVEC, K. (2006): Identifikacija i prognoza minimalnih razina podzemne vode zagrebačkoga aluvijalnog vodonosnika modelima recesijskih krivulja [Identification and prediction of minimum ground water levels of Zagreb alluvial aquifer using recession curve models - in Croatian].- Unpub. $\mathrm{PhD}$ Thesis, Faculty of Mining, Geology and Petroleum Engineering, University of Zagreb, Zagreb, 89 p.

PUIGDOMENECH, I. (2006): HYDRA (Hydrochemical Equilibrium-Constant Database) and MEDUSA (Make Equilibrium Diagrams Using Sophisticated Algorithms) Programs. Royal Institute of Technology, Stockholm. http://www.kemi. kth.se/medusa/

RUŽIČIĆ, S., MILEUSNIĆ, M. \& POSAVEC, K. (2012): Building Conceptual and Mathematical Model for Water Flow and Solute Transport in the Unsaturated zone at Kosnica Site.- Rudarsko-geološko-naftni zbornik (0353-4529), 25, 21-31.

SOKAČ, A. (1978): Pleistocene ostracode fauna of the Pannonian Basin in Croatia. Paleont. Jugoslav., 21, 1-51.

SOLLITTO, D., ROMIĆ, M., CASTRIGNANO, A., ROMIĆ, D. \& BAKIĆ, H. (2010): Assessing heavy metal contamination in soils of the Zagreb region (Northwest Croatia) using multivariate geostatistics.- Catena, 80, 182-194. doi: 10.1016/j. catena.2009.11.005

UDOVIČIĆ, M., BAŽDARIĆ, K., BILIĆ-ZULE, L. \& PETROVEČKI, M. (2007): Što treba znati kada izračunavamo koeficijent korelacije? [What we need to know when calculating the coefficient of correlation?].- Biochemia Medica, 17/1,1-138.

VLAHOVIĆ, T., BAČANI, A. \& POSAVEC, K. (2009): Hydrogeochemical stratification of the unconfined Samobor aquifer (Zagreb, Croatia).- Environmental Geology, 57/8, 1707-1722. doi: 10.1007/s00254-008-1452-4.

VELIĆ, J. \& DURN, G. (1993): Alternating Lacustrine-Marsh Sedimentation and Subaerial Exposure Phases during Quaternary: Prečko, Zagreb, Croatia.- Geologia Croatica, 46/1, 71-90. doi: 10.4154/GC.1993.06

VELIĆ, J. \& SAFTIĆ, B. (1991): Subsurface Spreading and Facies Characteristics of Middle Peistocene Deposits Between Zaprešić and Samobor.- Geološki vjesnik, 44, 69-82.

VIDAL, M., MELGAR, J., LOPEZ, A. \& SANTOALLA, M.C. (2000): Spatial and temporal hydrochemical changes in groundwater under the contaminating effects of fertilizers and wastewater-- Journal of Environmental Management, 60/3,215-225. doi: 10.1006/jema.2000.0379 